\title{
Pertanian Tanaman Jagung dengan Alat Penyiang bagi Petani Jagung Desa Pulungdowo Kabupaten Malang
}

\author{
M. Akhlis Rizza1, Ratna Monasari², Zakki Fuadi Emzain ${ }^{3}$, Lisa Agustriyana ${ }^{4}$ \\ Jurusan Teknik Mesin, Politeknik Negeri Malang ${ }^{1,2,3,4}$ \\ Jl. Soekarno Hatta No.9, Jatimulyo, Kec. Lowokwaru, Kota Malang, Jawa Timur 65141 \\ Email: muh.akhlis@polinema.ac.id
}

\begin{abstract}
ABSTRAK
Saat ini kebutuhan jagung dunia semakin meningkat, dengan pemanfaatan yang luas seperti konsumsi manusia, pakan ternak, hingga kebutuhan industri. Menurut data Kementerian Pertanian, Kabupaten Malang merupakan salah satu sentra produksi tanaman palawija khususnya jagung di Indonesia. Namun saat ini berdasarkan data BPS, hasil produksi jagung di Kabupaten Malang mengalami penurunan. Hal ini terjadi karena kapasitas kerja pengolahan tanah yang dilakukan oleh petani Desa Pulungdowo tidak maksimal dikarenakan usia petani yang sudah tidak produktif untuk melakukan pengolahan tanah. Untuk meningkatkan hasil produksi jagung perlu dilakukan peningkatan SDM dan mekanisasi pertanian. Kebutuhan mekanisasi pertanian di Desa Pulungdowo merupakan sebuah alat pengolahan tanah cultivator yang dapat dimanfaatkan sebagai alat penyiang rumput yang juga dapat dimanfaatkan untuk menggemburkan tanah pada lahan kering. Dengan mekanisasi ini mutu pekerjaan pengolahan tanah menjadi lebih baik, selain itu lebih efisien dalam waktu dan biaya yang dikeluarkan. Kegiatan ini melibatkan petani jagung Desa Pulungdowo dan pemateri yang memberikan penyuluhan mengenai pembibitan tanaman jagung yang dilakukan secara persilangan. Metode yang digunakan pada kegiatan PKM ini adalah dengan melibatkan masyarakat dan memberikan solusi substitusi IPTEK berupa mekanisasi pertanian. Tahapan pelaksanaan kegiatan ini adalah rembug desa yang merupakan bentuk dari survei lapangan, pengadaan alat, penyuluhan mekanisasi pertanian dan pembibitan tanaman jagung, penyerahan alat dan pelatihan operasional perawatan mesin, serta evaluasi untuk mengetahui efektivitas alat. Kegiatan ini menghasilkan evaluasi yang menunjukkan bahwa petani jagung Desa Pulungdowo mampu mengoperasikan alat cultivator setelah dilakukan pelatihan penggunaan dan perawatan mesin, sehingga proses pengolahan tanah pertanian jagung yang dilakukan petani Desa Pulungdowo menjadi lebih efisien.
\end{abstract}

Kata kunci: jagung, mekanisme pertanian, cultivator

\section{ABSTRACT}

Currently, the world's need for corn is increasing, with wide use of such as human consumption, animal feed, to industrial needs. According to data from the Ministry of Agriculture, Malang Regency is one of the production centers for secondary crops, especially maize in Indonesia. However, currently based on BPS data, corn production in Malang Regency has decreased. This happens because the working capacity of land cultivation carried out by the farmers in Pulungdowo Village is not optimal due to the age of the farmers who are not productive enough to cultivate the land. To increase the yield of maize production, it is necessary to increase human resources and agricultural mechanization. The need for agricultural mechanization in Pulungdowo Village is a tool for cultivating land for cultivators that can be used as a tool for weeding which can also be used to loosen the soil on dry land. With this mechanization, the quality of soil processing work will be better, besides that it is more efficient in terms of time and costs. This activity involved corn farmers in Pulungdowo Village and presenters who provided counseling on the breeding of corn which was carried out by crosses. The method used in this PKM activity is to involve the community and provide solutions to substitute science and technology in the form of agricultural mechanization. The stages of the implementation of this activity are village consultations which are a form of field survey, procurement of tools, counseling on agricultural mechanization and corn plant nurseries, delivery of tools 
and training on machine maintenance operations, and evaluation to determine the effectiveness of the tools. This activity resulted in an evaluation showing that the corn farmers in Pulungdowo Village were able to operate the cultivators after training on the use and maintenance of the machines so that the processing of corn farmland carried out by the farmers in Pulungdowo Village became more efficient.

Keywords: corn, farm mechanism, cultivator

\section{PENDAHULUAN}

Saat ini pengembangan agroindustri terus digalangkan, inovasi teknologi dan peran dari lembaga atau institusi merupakan upaya dalam peningkatan produktivitas dan efisiensi dari produksi pertanian. Salah satu upaya pengembangan agroindustri yaitu dengan pemanfaatan teknologi mekanisasi. Sebagai upaya mewujudkan industri pertanian yang efisien, berkelanjutan dan berdaya saing tinggi perlu menggiatkan desa yang mandiri dalam pertumbuhan agroindustri serta didukung oleh teknologi mekanisasi pertanian. Permasalahan dan kendala yang dihadapi dalam pengembangan mekanisasi pertanian diantaranya kepemilikan lahan yang terbatas, lemahnya modal usaha tani, rendahnya tingkat pendidikan dan pengetahuan serta keterampilan petani.

Efisiensi dan produktivitas kerja dari alat mesin pertanian (alsintan) berkurang karena faktor kepemilikan lahan pertanian yang sempit. Selain itu permasalahan seperti terbatasnya modal, tingkat pendidikan dan pengetahuan yang rendah serta keterampilan dan budaya tradisional yang masih kuat juga menjadi penghambat dalam pengembangan teknologi mekanisasi (Hadi, 2014). Selain itu dengan terbatasnya prasarana pertanian seperti jalan menuju lokasi usaha tani maupun bengkel tempat perbaikan alsintan, dapat mengurangi mobilitas operasional dan produktivitas kerja dari alsintan yang menjadikan waktu pengoperasian alsintan tidak optimal. Kondisi wilayah yang beragam, sosial ekonomi petani, prasarana dan kelembagaan penunjang menuntut kehati-hatian dalam menerapkan teknologi mekasasi yang sesuai dengan kondisi dan kebutuhan. Para petani umumnya tidak serta merta dapat menerima teknologi mekanisasi karena ketidaksesuaian hal - hal yang disebutkan tadi. Apabila pengembangan teknologi mekanisasi dilanjutkan tanpa memperhatikan hal tersebut maka mekanisasi pertanian yang diteraokan tidak mampu memberikan hasil yang optimal pada produksi pertanian yang dihasilkan (Mislaini dan Khandra, 2017).

Untuk meningkatkan ketersediaan pangan, cara yang dapat dilakukan yaitu mengembangkan tanaman palawija. Selain itu dengan pengembangan tanaman palawija juga mampu menarik masyarakat berpenghasilan rendah sebagai sumber bahan pangan pengganti (Rudi dan Trias, 2017). Seiring dengan meningkatnya laju pertumbuhan 
penduduk menjadikan kebutuhan pangan juga semakin meningkat sehingga para ahli tergugah untuk melakukan berbagai penelitian dan pengembangan teknologi untuk meningkatkan ketersediaan tanaman palawija.

Saat ini jagung merupakan salah satu komoditi palawija utama di Indonesia dengan luas panen mencapai $42-46 \%$ dari total luas panen palawija. Jagung memiliki potensi produksi yang besar dengan prospek pemanfaatan yang baik sebagai bahan pangan dan pakan ternak. Faktor yang mempengaruhi produktivitas jagung diantaranya seperti tempat tumbuh atau keadaan tanah dan jarak tanamnya. Faktor ini perlu diperhatikan untuk menghasilkan tanaman jagung yang tumbuh dengan baik dan memiliki tongkol dan biji yang banyak. Secara umum ada beberapa kondisi yang diperlukan sebagai lahan pertanian tanaman jagung (Purwono dan Hartono, 2007), diantaranya: (i) Jenis tanah yang dapat ditanami jagung antara lain latosol, andosol, dan grumusol. Pada dasarnya tanah yang dijadikan media tanam memerlukan pengolahan yang baik serta sistem aerasi dan drainase yang baik pula. (ii) Tanah yang digunakan sebagai media tanam memliki keasaman 5,6 7,5 agar pertumbuhan jagung berlangsung dengan baik. (iii) Tanaman jagung sendiri memerlukan tanah dengan aerasi dan ketersediaan air dengan kondisi baik.

Pengolahan tanah merupakan kegiatan yang paling membutuhkan energi dalam budi daya tanaman. Untuk menciptakan lingkungan fisik tanah yang kondusif bagi pertumbuhan tanaman perlu dilakukan tahap pengolahan tanah. Menutut Oisat sistem pengolahan tanah terbagi menjadi dua, yaitu pengolahan secara konvensional dan konservatif. Pengolahan tanah secara konservatif dilakukan dengan cara mencangkul, membajak, atau menggunakan peralatan mekanis lainnya untuk mempersiapkan lahan bagi budi daya tanaman. Keuntungan pengolahan tanah dengan cara konservatif yaitu mampu mengendalikan gulma, memutus siklus hidup hama, memperbaiki aerasi tanah, dan memudahkan untuk aktivitas budi daya lainnya.

Budidaya pertanian yang dilakukan petani Desa Pulungdowo dalam pengolahan tanah sebagai media tanam masih tergolong tradisional dan semi teknis. Dalam proses persiapan tanah sebagai media tanam, petani masih banyak yang mengandalkan tenaga manusia. Petani dengan usia produktif pada Desa Pulungdowo sendiri berjumlah sedikit. Sehingga dalam melakukan proses ini waktu yang dibutuhkan relatif lama, membutuhkan waktu sekitar 44 jam kerja/ha. Hal ini tentunya mempengaruhi produktivitas proses pertanian itu sendiri. Sementara itu disisi lain pemanfaatan teknologi mekanisasi dalam pengolahan tanah jika menggunakan mesin - mesin pertanian dapat meningkatkan kapasitas dan produktifitas. 
Pelaksanaan program pengabdian kepada masyarakat (PKM) ini akan bermitra dengan Kelompok Tani (Poktan) Tani Karya 02 Desa Pulungdowo Kecamatan Tumpang Kabupaten Malang. Dampak keberadaan mitra terhadap lingkungan sangat berpengaruh, karena mitra akan menjadi pelopor dalam pengembangan teknologi mekanisasi pertanian pada Kabupatan Malang. Pemilihan mitra didasari pada keaktifan suatu kelompok tani, sehingga nantinya diharapkan dapat menjadi contoh bagi kompok tani lainnya untuk menerapkan teknologi mekanisasi bagi lahan pertaniannya.

\section{METODE PELAKSANAAN}

Dalam pelaksanaan program kegiatan Pengabdian Kepada Masyarakat (PKM) setelah menetapkan kegiatan yang berupa substitusi IPTEKS dengan aktifitas mekanisasi pertanian sebagai kegiatan utama, maka beberapa tahapan yang dilakukan sebagai berikut:

1. Persiapan rembug desa

Rembug desa dihadiri oleh pihak Kecamatan Tumpang, pihak Desa Pulungdowo, dan kelompok tani. Pada tahap kegiatan ini pembahasan mengenai pelaksanaan mekanisasi pertanian sebagai solusi untuk meningkatkan produksi pertanian jagung. Metode kegiatan yang dilakukan adalah partisipatif dan aksi yang melibatkan kelompok tani dan tim PKM yang bertindak sebagai fasilitator. Dalam tahap ini fasilitator juga mendengarkan keluhan dan kesulitan kelompok tani dalam pengolahan tanah sebagai persiapan media tanam bagi tanaman jagung. Terbatasnya jumlah petani muda menyulitkan proses pengolahan tanah sehingga diperlukan waktu yang relatif lama untuk proses tersebut. Dengan tahap ini antara fasilitator dengan kelompok tani menemukan titik temu untuk menerapkan mekanisasi pertanian yang cocok bagi Desa Pulungdowo.

2. Pelatihan pengoperasian alat dan penyuluhan mengenai pembibitan jagung

Tahap kegiatan ini dilakukan dengan menerjunkan anggota tim PKM untuk melakukan pelatihan, pendampingan dan praktek penggunaan alsintan pada kelompok tani. Alsintan yang dipilih sebagai mekanisasi pertanian disini adalah cultivator, sesuai dengan kebutuhan yang disampaikan kelompok tani pada tahap kegiatan pertama. Metode yang digunakan dengan cara melibatkan masyarakat secara partisipatif. Pada saat materi pelatihan pembelajaran diberikan secara andragogi kepada para kelompok tani dengan pembukaan secara teori kemudian dilanjutkan dengan praktek penggunaan alsintan. Selain itu tahap kegiatan ini juga diadakan penyuluhan oleh ahli pertanian untuk memberikan pengetahuan pembibitan tanaman jagung dengan cara yang tepat, efektif, dan murah. Pembelajaran yang diberikan harus memperhatikan beberapa hal seperti memberi nilai manfaat, praktis, menarik, aktif, dan meberikan solusi terhadap masalah yang dialami. 


\section{HASIL DAN PEMBAHASAN}

\section{Profil Kelompok Tani}

Kabupaten Malang merupakan salah satu sentra daerah penghasil jagung di wilayah Indonesia timur. Hasil panen jagung sejak 2013 - 2018 dapat dilihat pada gambar 1. yang bersumber dari Badan Pusat Statistik (BPS) Kabupaten Malang (BPS Kabupaten Malang, 2018)

Hasil Panen Jagung Kabupaten Malang

(Ton)

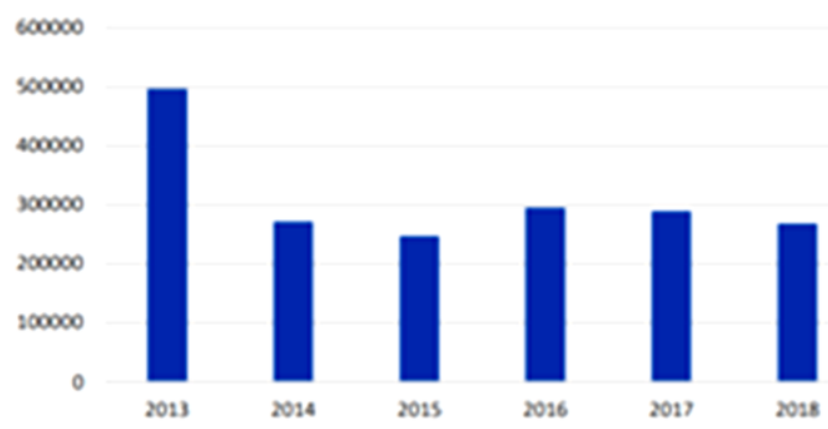

Gambar 1. Hasil Panen Jagung Kabupaten Malang

Jumlah hasil panen tanaman jagung tercatat tidak stabil, cenderung menurun. Hal ini disebabkan oleh beberapa hal, salah satunya luas lahan yang semakin sempit dan teknik pengolahan lahan yang cenderung masih tradisional. Desa Pulungdowo merupakan pedesaan di Kabupaten Malang yang perekonomian masyarakatnya bergantung pada sektor pertanian. Jumlah penduduk Desa Pulungdowo adalah 8094 jiwa yang kebutuhan pangannya harus terpenuhi. Dengan luas daerah pertanian lebih dari 50\% menjadikan Desa Pulungdowo salah satu desa penghasil jagung terbesar di Kecamatan Tumpang. Berdasarkan data BPS, hasil panen jagung pada Kecamatan Tumpang juga cenderung mengalami penurunan (BPS Kabupaten Malang, 2018).

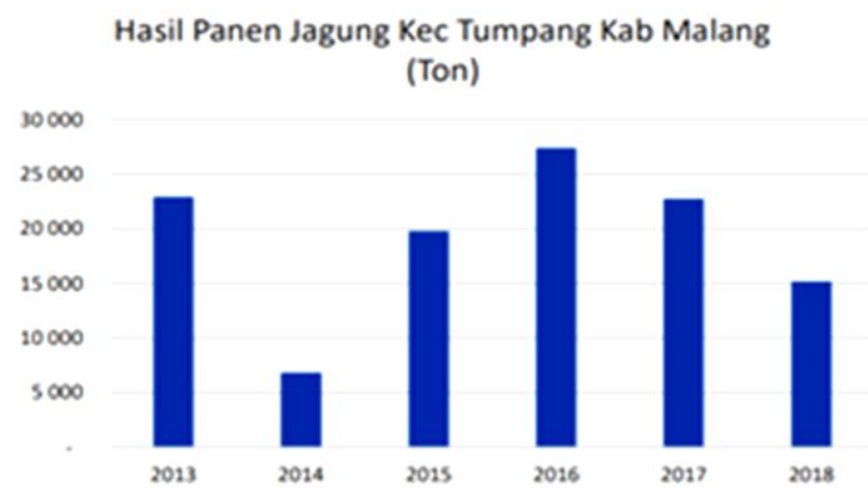

Gambar 2. Hasil Panen Jagung Kecamatan Tumpang

Berdasarkan data diatas produksi jagung pada Desa Pulungdowo masih dapat 
ditingkatkan, meskipun kondisi lahan yang semakin terbatas. Selain itu pemanfaatan lahan pertanian juga bergantung pada musim. Ketika musim hujan, komoditi yang ditanam oleh petani adalah padi, sedangkan pada musim kemarau awal dan akhir tahun komoditi yang ditanam adalah padi dan jagung. Hasil dan mutu pertanian pada Desa Pulungdowo kurang begitu maksimal. Faktor lain selain lahan yang terbatas ialah pemanfaatan teknologi pertanian yang masih tradisional, salah satunya pengolahan tanah yang dilakukan dengan tenaga manusia dengan penggarap sawah yang merupakan generasi tua. Hanya terdapat $20 \%$ generasi muda yang berkontribusi pada sektor pertanian, mereka lebih tertarik melakukan urbanisasi ke kota besar untuk melakukan pekerjaan lain karena menganggap sektor pertanian kurang menjanjikan. Apabila hal ini tidak diatasi maka dapat terjadi krisis pangan nantinya. Oleh karena itu percepatan dan penerapan mekanisasi pertanian perlu segera dilakukan (BPS Kabupaten Malang, 2018).

\section{Kegiatan PKM}

Pelaksanaan kegiatan program pengabdian kepada masyarakat (PKM) dengan judul Peningkatan Hasil Produksi Jagung Dengan Mekanisasi Pertanian Di Desa Pulungdowo Kecamatan Tumpang Kabupateng Malang. Kegiatan ini telah melalui beberapa tahapan yaitu dimulai dengan pengajuan proposal PKM, pengumuman penerima hibah, kemudian dilanjutkan dengan penandatanganan kontrak. Pengabdian kepada masyarakat ini dibiayai dengan dana DIPA Politeknik Negeri Malang. Tim pelaksana kegiatan pengabdian kepada masyarakat ini terdiri dari ketua dan tiga orang anggota yang dibantu oleh pihak ahli pertanian sebagai mitra ahli pertanian. Beberapa kegiatan yang dilakukan diantaranya:

1. Diskusi dan pengumpulan referensi. Diskusi dilakukan antara tim pelaksana dan kelompok Tani Karya 02 sebagai mitra untuk menemukan solusi dari permasalahan yang ada seperti pada gambar 2A. Mencari referensi mengenai alsintan pengolahan tanah jenis cultivator yang diberikan kepada mitra sebagai pelaku usaha untuk meningkatkan mutu pekerjaan pengolahan tanah, serta meningkatkan efisiensi dalam waktu dan biaya untuk melakukan pekerjaan pengolahan tanah pertanian.

2. Melakukan pengadaan mesin pengolah tanah cultivator dengan rotary blade. Jenis alsintan cultivator ini merupakan solusi mekanisasi yang sangat dibutuhkan kelompok Tani Karya 02. Dengan mesin cultivator ini, pekerjaan pengolahan tanah dapat dikerjakan dengan waktu yang singkat juga biaya produksi yang lebih murah dibandingkan menggunakan tenaga manusia dalam pengolahan tanah pertanian. Oleh karena hal ini, mutu pekerjaan pengolahan tanah akan menjadi lebih baik. Setelah itu 
melakukan uji coba mesin dengan melibatkan ketua kelompok tani dalam prosesnya.

3. Pelatihan pengoperasian dan perawatan mesin cultivator dilaksanakan pada balai Desa Pulungdowo yang mendatangkan ahli permesinan dari Polinema. Peserta pelatihan terdiri dari petani kelompok Tani Karya 02 yang dapat dilihat pada gambar $2 b$.

4. Sosialisasi mengoptimalkan produksi hasil panen jagung dengan metode pengembangan varietas jagung di Desa Pulungdowo dapat dilihat pada gambar 3. dengan persilangan antar varietas akan diperoleh hasil panen berkualitas.
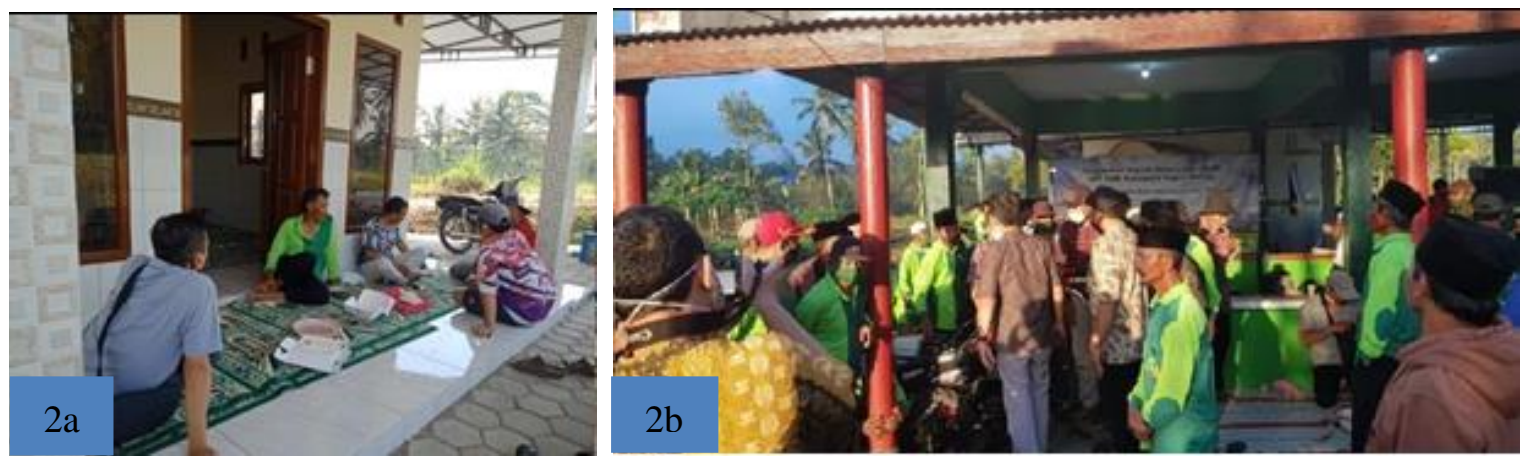

Gambar 2a. Diskusi dengan ketua kelompok tani karya 02, Gambar 2b. Pelatihan pengoperasian alat

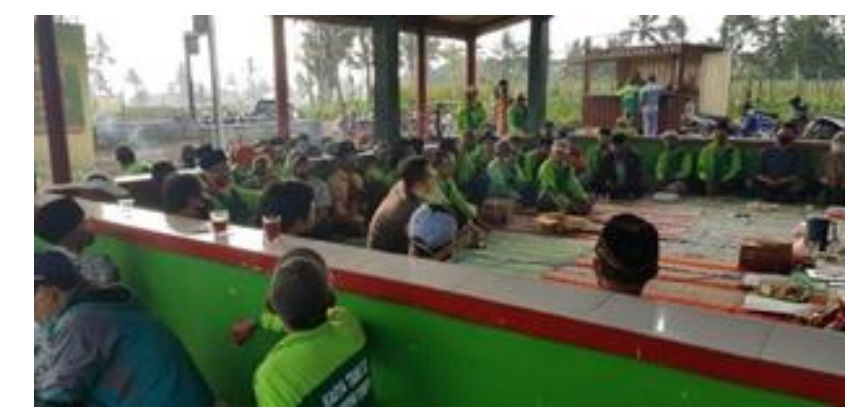

Gambar 3. Penyuluhan mengoptimalkan hasil panen

\section{Mekanisasi Pertanian}

Alat pengolah tanah merupakan pengaplikasian alsintan yang paling sering digunakan dalam proses penanaman tanaman pangan seperti jagung (Herren, 2010). Pengolahan tanah bertujuan untuk menciptakan kondisi biologis tanah yang baik dan kondisi fisik yang khemis sampai kedalaman tertentu untuk menciptakan pertumbuhan tanaman yang baik. Proses pengolahan tanah juga bertujuan untuk membasmi gulma dan tanaman lain yang tidak diinginkan pada proses pertanian. Pengolahan tanah juga dilakukan untuk meratakan tanah sehingga memudahkan pekerjaan di lapangan, selain itu juga dapat menyatukan pupuk dengan tanah serta mempersiapkan tanah untuk mendapatkan pengairan.

Berdasarkan pada tahapan kegiatan, hasil kerja dan dalamnya tanah yang diolah, 
kegiatan pengolahan tanah dibedakan mejadi dua yaitu pengolahan tanah tahap awal dan pengolahan tanah tahap kedua. Pada tahap pertama, tanah dipotong yang kemudian diangkat lalu dibalik agar sisa tanaman yang ada dipermukaan tanah dapat terbenam ke dalam tanah. Pada tahap pengolahan tanah kedua, bongkah tanah dan sisa tanaman yang terpotong pada tahap pengolahan pertama akan dihancurkan menjadi lebih halus sekaligus mencampurnya dengan tanah.

Dalam kegiatan pelatihan pengoperasian alat mesin pertanian cultivator didahului dengan kegiatan penyerahan dan penyuluhan yang dilaksanakan pada tanggal 28 Agustus 2020. Pelatihan pengoperasian alat disampaikan oleh Bapak Zakki Fuadi Emzain sebagai tim ahli teknik mesin dari Polinema tentang alat pengolahan tanah berupa cultivator. Dalam kegiatan ini antusias petani terlihat jelas, hal ini terbukti dari kehadiran anggota kelompok tani yang berjumlah 56 orang serta partisipasi para petani pada saat pelaksanaan program.

\section{Alat penyiang mekanis (cultivator)}

Alat penyiang mekanis seperti cultivator merupakan alat pengolah tanah untuk pemeliharaan tanaman. Umumnya peralatan ini digunakan setelah kegiatan penanaman dilakukan. Dalam artian luas alat penyiang mekanis seperti cultivator ini dapat digunakan sebelum maupun sesudah tanam sebagai salah satu peralatan pengolahan tanah. Salah satu fungsi utama alat ini juga sebagai pengendalian gulma, penyiangan yang dilakukan untuk mencabut gulam yang berada di sela - sela tanaman pertanian dan sekaligus menggemburkan tanah. Keuntungan penyiangan dengan alat ini antara lain: ramah lingkungan, ekonomis, hemat tenaga, meningkatkan kandungan udara dalam tanah. Penyiangan dengan menggunakan tenaga manusia diperoleh sebesar 0,0277 Ha/jam, sedangkan dengan menggunakan alat mekanis pertanian terbilang efektif dan efisien. Dari segi waktu dihasilkan $0,8033 \mathrm{Ha} / \mathrm{jam}$.

Cultivator dibuat dengan besi cor untuk menjamin kekuatan pada saat mengolah berbagai jenis lahan. Dengan teknologi terkini berupa berbagai macam implement tersedia untuk memenuhi kebutuhan pengolahan berbagai jenis lahan, dimulai dari pembajakan, pencacahan, penyiangan, hingga pembuatan gludan atau bedengan dapat dilakukan dengan satu alat. Lebar dari kerja dan kecepatan putar pada alat ini juga dapat diatur untuk menyesuaikan kebutuhan tanam sehingga mengoptimalkan hasil pengolahan. Aspek terkahir yang sangat penting yaitu keamanan dan kenyamanan dalam penggunaan alat. Cultivator dengan desai ketinggian hand dan lebar yang dapat disesuaikan dengan operator. Tuas pada alat ini pun terletak di lokasi yang mudah dijangkau oleh tangan operator, 
sehingga sangat aman pada saat penggunaannya.

\section{Serah terima alat kepada mitra (Kelompok Tani Karya 02)}

Penyerahan alat diserahkan kepada kelompok tani untuk dapat digunakan petani pada Desa Pulungdowo. Kegiatan dilaksanakan pada tanggal 28 Agustus 2020 disaksikan oleh Bapak Sukarlin selaku Camat Tumpang dan Bapak Jangkung Abdi Prayugo selaku Kepala Desa Pulungdowo dapat dilihat pada gambar 4.

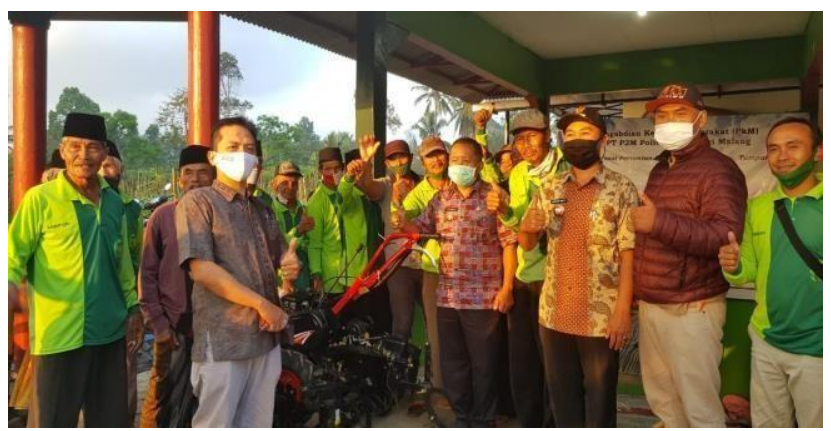

Gambar 4. Penyerahan mesin cultivator kepada kelompok tani

\section{SIMPULAN}

Paparan diatas merupakan hasil pelaksanaan kegiatan pengabdian kepada masyarakat (PKM) yang dilaksanakan pada kelompok tani di Desa Pulungdowo Kecamatan Tumpang Kabupaten Malang, kesimpulan yang dapat diambil sebagai berikut: (i) Mekanisasi pertanian di Desa Pulungdowo yang dilakukan melalui kegiatan PKM digelar guna meningkatkan produktivitas sektor pertanian serta penerapan teknologi tepat guna. Alat pengolahan tanah berupa cultivator telah diserahkan kepada kelompok Tani Karya 02 dan berfungsi dengan baik. (ii) Penggunaan cultivator dapat mempermudah proses pengolahan tanah, mempersingkat waktu, dan biaya dalam proses pengolahan tanah yang selama ini dilakukan secara tradisional dengan tenaga manusia. Mesin cultivator bermanfaat bagi petani usia lanjut pada Desa Pulungdowo dikarenakan regenerasi petani pada Desa Pulungdowo sangat sulit dilakukan. Sebagian besar petani di Desa Pulungdowo berusia diatas 45 tahun. Hal ini tentunya menjadi sesuatu yang sangat membutuhkan usaha besar untuk melakukan proses pengolahan tanah seperti mencangkul dan menggemburkan tanah pertanian. (iii) Pelatihan pengoperasian dan perawatan mesin cultivator telah dilakukan kepada kelompok Tani Karya 02. (iv) Selain pemberian alat dan pelatihan mesin cultivator, kegiatan sosialisasi dan penyuluhan untuk mengoptimalkan hasil panen jagung dengan metode pengembangan varietas jagung yang dilakukan dengan persilangan antar varietas mendukung ketahanan pangan daerah dan meningkatkan kualitas jagung yang dihasilkan. 


\section{UCAPAN TERIMA KASIH}

Kegiatan pengabdian kepada masyarakat ini dapat terwujud dan berjalan dengan baik berkat bantuan berbagai pihak. Terima kasih penulis ucapkan kepada Politeknik Negeri Malang atas dukungan dalam pembiayaan yang bersumber dari dana DIPA Nomer: SP DIPA-023.18.2.677606/2020 Politeknik Negeri Malang dan kepada Kelompok Tani Karya 02 Desa Pulungdowo Kecamatan Tumpang, Kabupaten Malang.

\section{DAFTAR PUSTAKA}

Hadi, Suyanto. 2014. Membangun Ketahanan Pangan Dan Teknologi Produktivitas Pertanian. [online]. Tersedia: http://staff.unila.ac.id/bungdarwin/files/2014/04/kel3-KETAHANANPANGAN-DAN-TEKNOLOGI-PRODUKTIVITAS.pdf. Diakses tanggal 26 Oktober 2020.

Herren, R. V. (2010). Agricultural mechanics: Fundamentals \& applications (6th ed.). Clifton Park, NY: Delmar.

Rudi H.P. dan Trias Q.D, 2017. Panduan Praktis Budidaya Jagung. Penebar Swadaya. Jakarta.

BPS Kabupaten Malang. (2018). Kabupaten Malang dalam Angka. Kabupaten Malang: Pemerintah Kabupaten Malang.

Purwono dan Rudi Hartono. 2007. Bertanam Jagung Unggul. Penebar Swadaya. Jakarta.

Nuriyanti, Rofikha. Supratiningsih, Linda K. 2019. PKM Mesin Power Thresher: Solusi Ketahanan Pangan Bagi Petani Di Kabupaten Probolinggo. Tulungagung.

Widodo, Wahyu. 2010. Upaya Regenerasi Petani Di Desa Sambirejo Trenggalek Melalui Solar-8. Universitas Negeri Malang. Malang.

Rizaldi, Taufik. 2006. Mesin Peralatan. Departemen Teknologi Pertanian, Fakultas Pertanian, Universitas Sumatera Utara. Medan.

R. Mislaini., Fahmy Khandra. 2017. Penerapan Teknologi Pertanian Melalui Penggunaan Alsintan Pada Lahan Sawah Kepada Masyarakat Tani di Nagari Minangkabau Kec. Sungayang Kab. Tanah Datar. Prodi Teknik Pertanian, Fakultas Teknologi Pertanian, Universitas Andalas. Padang. 